University of South Florida

DIGITAL COMMONS

Digital Commons @ University of

@ UNIVERSITY OF SOUTH FLORIDA

South Florida

$1-1-2012$

\title{
2012 Work Plan USF Sarasota-Manatee
}

USF

Follow this and additional works at: https://digitalcommons.usf.edu/usf_accountability_reports

\section{Scholar Commons Citation}

USF, "2012 Work Plan USF Sarasota-Manatee" (2012). USF Accountability Reports. 30.

https://digitalcommons.usf.edu/usf_accountability_reports/30

This Article is brought to you for free and open access by the USF Archives at Digital Commons @ University of South Florida. It has been accepted for inclusion in USF Accountability Reports by an authorized administrator of Digital Commons @ University of South Florida. For more information, please contact digitalcommons@usf.edu. 


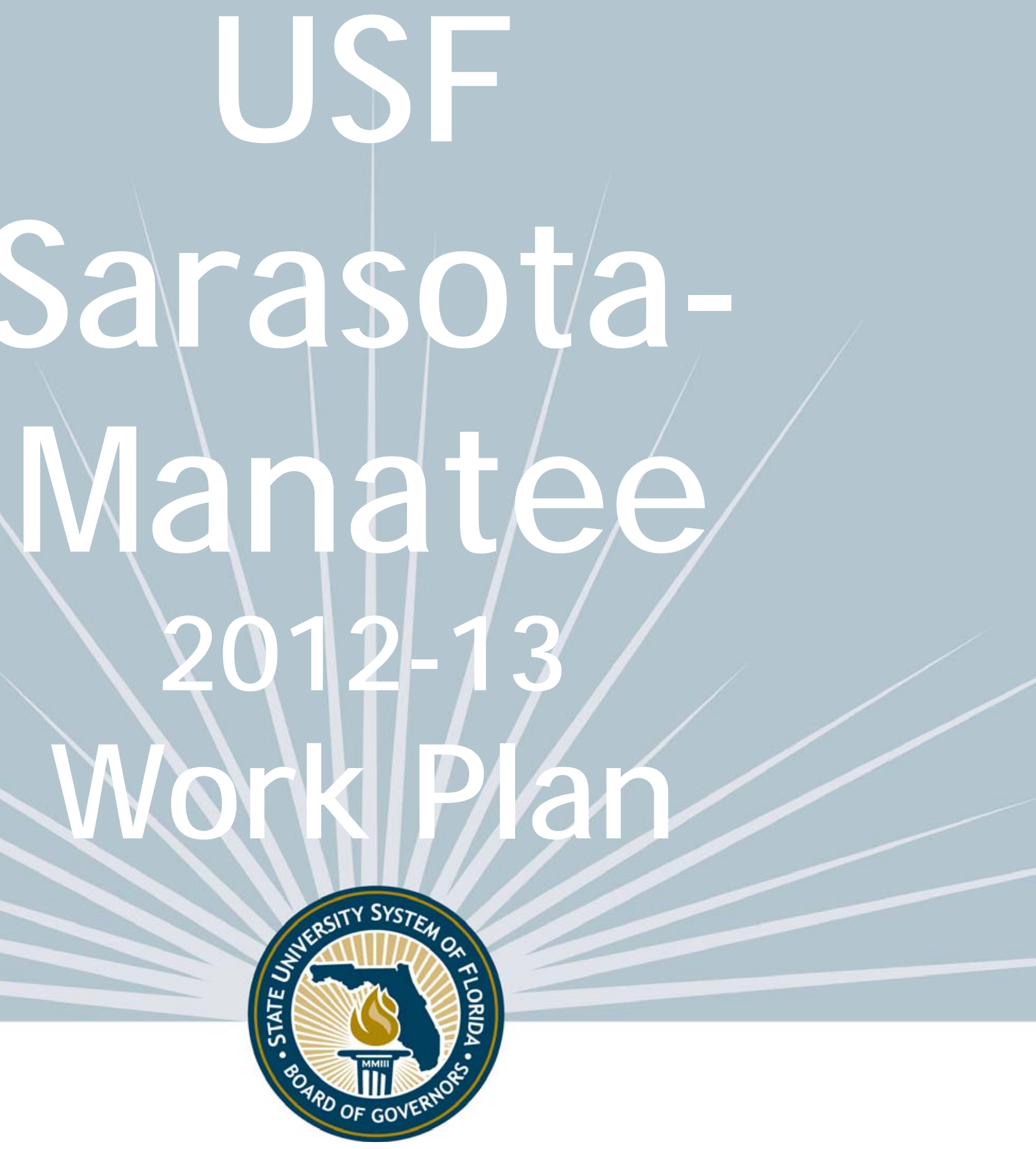

University of South Florida Sarasota-Manatee

Work Plan Presentation for 2012-13 Board of Governors Review

Approved by the USF System BOT - June 14, 2012 STATE UNIVERSITY SYSTEM of FLORIDA $\mid$ Board of Governors 


\section{INTRODUCTION}

The State University System of Florida has developed three tools that aid in guiding the System's future.

1) The Board of Governors' new Strategic Plan 2012-2025 is driven by goals and associated metrics that stake out where the System is headed;

2) The Board's Annual Accountability Report provides yearly tracking for how the System is progressing toward its goals;

3) Institutional Work Plans connect the two and create an opportunity for greater dialogue relative to how each institution contributes to the System's overall vision.

These three documents assist the Board with strategic planning and with setting short-, mid- and long-term goals. They also enhance the System's commitment to accountability and driving improvements in three primary areas of focus: 1) academic quality, 2) operational efficiency; and, 3) return on investment.

The Board will use these documents to help advocate for all System institutions and foster even greater coordination with the institutions and their Boards of Trustees.

Once a Work Plan is approved by each institution's respective Boards of Trustees, the Board of Governors will review and consider the plan for potential acceptance of 2012-13 components. Longer-term components will inform future agendas of the Board's Strategic Planning Committee. The Board's acceptance of a work plan does not constitute approval of any particular component, nor does it supersede any necessary approval processes that may be required for each component. 


\section{TABLE OF CONTENTS}

1. STRATEGY
a. Mission Statement
b. Vision Statement
c. Statement of Strategy
d. Strengths and Opportunities
e. Key Initiatives \& Investments

\section{KEY PERFORMANCE INDICATORS}

a. Goals Common to All Universities

b. Goals Specific to Research Universities

c. Institution Specific Goals

3. OPERATIONS
a. Fiscal Information (includes Tuition Differential Fee Request)
b. Enrollment Planning
c. Academic Program Coordination

\section{DEFINITIONS}




\section{MSSION STATEMENT (What is your purpose?)}

The University of South Florida Sarasota-Manatee provides access to professional higher education programs and scholarly research in a personalized living and learning community that graduates successful leaders who empower Florida's Suncoast to thrive locally, nationally, and globally.

\section{VSON STATEMENT (What do you aspire to?)}

The University of South Florida Sarasota-Manatee strives to be a hometown comprehensive university with ever-increasing national and global impact.

\section{STATEMENT OF STRATEGY (How will you get there?)}

\section{Given your mission, vision, strengths and available resources, provide a brief description of your} market and your strategy for addressing and leading it.

In keeping with our separate SACS accreditation, effective January 1, 2011, USF Sarasota-Manatee advances the Access = Success mission, which includes academic programs for lower-level students, including general education. The loss of high school graduates from Sarasota, Manatee, and DeSoto counties to other Florida counties causes a significant brain drain to our region. In 2010-11, the Florida Department of Education reported that 1,576 high school graduates in our three counties reported postgraduation plans to attend a public university in Florida. Other than the small number attending New College, the rest must leave our community to receive a four-year university education. Lower-division programs will enlarge the size of a university-educated work force and improve quality of life in our Suncoast region. USFSM has already begun to test the local demand and the University's ability to meet these needs by offering a few, select lower-level courses as a service to our entering transfer students. These classes have consistently filled and the number of credits hours generated has increased $500 \%$ over the past three years, indicating an even greater demand. USFSM plans to continue to address these needs by admitting 100 students for the full bachelor's degree program in Fall Semester 2013. Within the next three years, USFSM does not expect the student credit hours at the lower level to exceed $25 \%$ of our total student credit hours. 


\section{STRENGTHS AND OPPORTUNITIES (within 3 years)}

What are your core capabilities, opportunities and challenges for improvement?

USF Sarasota-Manatee is privileged to provide education that permits students to "learn where they earn." to participate in regional economic development, to link continuing professional training to maintain workforce competence, and to respond to the learning needs of a growing population. As a member of the USF System, USFSM benefits from the efficiency of shared resources, the opportunity for collaboration with other member institutions, and a unified brand that yields identity and impact. Currently, the University's steepest challenge is the decrease in general revenue funding. The campus will sustain a $\$ 1.3$ million cut to its base budget in the upcoming fiscal year.

\section{KEY INITIATIVES \& INVESTMENTS (within 3 years)}

Describe your top three key initiatives for the next three years that will drive improvement in Academic Quality, Operational Efficiency, and Return on Investment.

1. Provide lower-level classes - USF Sarasota-Manatee plans to add lower-level courses to improve access to four-year degrees for the over 1,500 high school graduates from Sarasota, Manatee, and DeSoto counties. These graduates now must leave the service area to attend other SUS Universities, which have become more competitive in their admissions and unable to accept all who apply. The addition of the full four-year program will be attractive to those with financial challenges, the need to work full-time and first-generation students who often prefer to stay close to their family and community. Within the next three years, USFSM does not expect the student credit hours at the lower level to exceed $25 \%$ of our total student credit hours.

\section{Develop programs based on their positive potential impact on the local community while also} serving state and national educational needs - In alignment with the Board of Governors identified areas of programmatic strategic emphasis, USFSM offers degree-programs in the critical needs areas of information technology and criminology, as well as special education through the Bay-to-Bay consortium. In 2011, USFSM received approval to offer the second bachelor's in communication sciences and disorders. The University also plans to partner with USF Tampa to host the complementary master's degree in this area as well. This spring, USFSM forged a partnership with Mote Marine Laboratory to phase in science education housed at the Mote campus and taught by Mote

3. Continue to improve baccalaureate retention and graduation rates - In addition to meeting the USFSM strategic goal of access, as documented in initiatives 1 and 2 above, the University will also strive to improve the success of students. Several initiatives have already been implemented including the use of an early alert system to identify students at risk who are matched with services to assist and support their achievement. USFSM leverages technology to improve student-learning outcomes and uses tuition differential funds to open additional undergraduate course sections, which can improve rates of graduation. 


\section{KEY PERFORMANCE INDICATORS}

The Board of Governors has selected the following Key Performance Indicators, from its 2012-2025 System Strategic Plan and from accountability metrics identified by the Florida Legislature. The Key Performance Indicators emphasize three primary areas of focus: Academic Quality, Operational Efficiency, and Return on Investment. The indicators address common goals across all universities while also providing flexibility to address institution-specific goals from a list of metrics in the 2012-2025 System Strategic Plan.

The Goals Specific to Research Universities apply only to those universities classified by the Carnegie Foundation for the Advancement of Teaching as being a 'Research University'1, which includes Florida A\&M University (by university request), Florida Atlantic University, Florida International University, Florida State University, University of Central Florida, University of Florida, and the University of South Florida.

1 The Carnegie Foundation for the Advancement of Teaching has developed a well-respected system of categorizing postsecondary institutions that includes consideration of each doctorate-granting university's research activities - for more information see link. 


\section{KEY PERFORMANCE INDICATORS}

\section{Goals Common to All Universities}

\begin{tabular}{l|ccccc} 
& 5 YEAR & & & & 3 YEAR \\
& TREND & $2010-11$ & $2011-12$ & $2012-13$ & GOALS \\
& (05-06 to 10-11) & ACTUAL & ESTIMATES & GOALS & (2014-15) \\
\hline Academic Quality & & & &
\end{tabular}

\section{National Ranking for University and Programs}

Describe plans for increasing national preeminence of University and select programs.

\section{Avg. SAT Score}

Avg. High School GPA (on 4.0 scale)

Professional/Licensure Exam

First-time Pass Rates ${ }^{2}$

Exams Above National/State Benchmark

Exams Below National/State Benchmark

Percent of Undergraduate Seniors

Participating in a Research Course

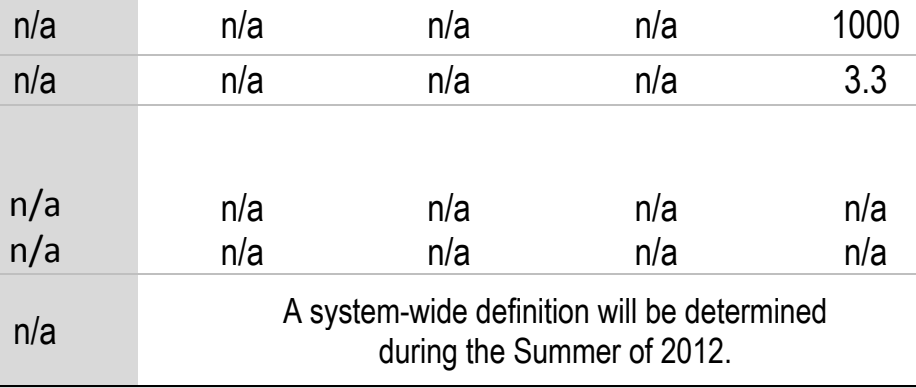

$\mathbf{x}$

$\mathbf{x}$

$\mathbf{x}$

$\mathbf{x}$

\section{Operational Efficiency}

\section{Freshman Retention Rate \\ FTIC Graduation Rates \\ In 4 years (or less) \\ In 6 years (or less)}

AA Transfer Graduation Rates

In 2 years (or less)

In 4 years (or less)

Percent of Bachelor's Degrees

Without Excess Hours

SUBTOTAL OF IMPROVING METRICS

\section{Return on Investment}

\section{Bachelor's Degrees Awarded}

Percent of Bachelor's Degrees in STEM

Graduate Degrees Awarded

Percent of Graduate Degrees in STEM

Percent of Baccalaureate Graduates

Employed in Florida

Percent of Baccalaureate Graduates

Continuing their Education (in FL)

Annual Gifts Received (\$M)

Endowment (\$M)

\section{SUBTOTAL OF IMPROVING METRICS}

TOTAL OF IMPROVING METRICS

\begin{tabular}{cc} 
n/a & n \\
\hline n/a & \\
n/a & \\
\hline & \\
$-2 \% *$ & $30 \%$ \\
$-4 \%^{*}$ & $56 \%$ \\
n/a & \\
\hline
\end{tabular}

$\mathbf{x}$ n/a

$\mathrm{n} / \mathrm{a}$

n/a

$30 \%$

$56 \%$ $\mathrm{n} / \mathrm{a}$

$\mathrm{n} / \mathrm{a}$

$\mathrm{n} / \mathrm{a}$

$31 \%$

$60 \%$

Board staff is currently updating the methodology for this metric.

$\begin{array}{cc}\mathrm{n} / \mathrm{a} & \mathrm{xx} \% \\ \mathrm{n} / \mathrm{a} & \mathrm{xx} \% \\ \mathrm{n} / \mathrm{a} & \mathrm{xx} \% \\ \mathrm{n} & 35 \% \\ 62 \% & 64 \%\end{array}$

$\mathbf{x}$

$\mathbf{x}$

\begin{tabular}{c|cccc}
\hline $26 \%$ & 454 & 494 & 524 & 588 \\
\hline$-1 \%$ & $3 \%$ & $3 \%$ & $4 \%$ & $5 \%$ \\
\hline$-62 \%^{*}$ & 68 & 73 & 70 & 90 \\
\hline n/a & $0 \%$ & $0 \%$ & $0 \%$ & $0 \%$ \\
\hline
\end{tabular}

$\% \Delta \quad$ Data available only at the USF System level

$\% \Delta \quad$ Data available only at the USF System level

$\% \Delta \quad$ Data available only at the USF System level

$\% \Delta \quad$ Data available only at the USF System level

$\mathbf{x}$

$\mathbf{x}$

$\mathbf{x}$

$\mathbf{x}$

$\mathbf{x}$

$\mathbf{x}$

$\mathbf{x}$

Notes: (1) SAT trends are based on 3 year average, (2) Professional licensure pass rates are based on the 2010-11 Annual Accountability Report with data that spans multiple time periods, (3) Percent of graduates employed and continuing their education is based on 2009-10 data from FETPIP. *In Fall 2009, USF Tampa mandated that any USFSM student in degree programs hosted by USF Tampa or not offered completely by USFSM be removed from USFSM Home Campus enrollment numbers. As a result of the mandate, USFSM graduation and retention rates were negatively affected. 


\section{KEY PERFORMANCE INDICATORS}

Goals Specific to Research Universities - Not Applicable

\begin{tabular}{|c|c|c|c|c|c|}
\hline & $\begin{array}{l}5 \text { YEAR } \\
\text { TREND } \\
\text { (2005-06 } \\
\text { to 2010-11) }\end{array}$ & $\begin{array}{r}2010-11 \\
\text { ACTUAL }\end{array}$ & $\begin{array}{c}2011-12 \\
\text { ESTIMATES }\end{array}$ & $\begin{array}{l}2012-13 \\
\text { GOALS }\end{array}$ & $\begin{array}{c}3 \text { YEAR } \\
\text { GOALS } \\
(2014-15)\end{array}$ \\
\hline \multicolumn{6}{|l|}{ Academic Quality } \\
\hline Faculty Awards & $\% \Delta$ & $\mathrm{X}^{1}$ & $x$ & $x$ & $x$ \\
\hline National Academy Members & $\% \Delta$ & $x$ & $x$ & $x$ & $x$ \\
\hline Number of Post-Doctoral Appointees & $\% \Delta$ & $x x$ & $x x$ & $x x$ & $x x$ \\
\hline $\begin{array}{l}\text { Number of Science \& Engineering } \\
\text { Disciplines Nationally Ranked in Top } 100 \\
\text { for Research Expenditures (based on } 8 \text { broad } \\
\text { discipline areas, and includes private universities) }\end{array}$ & $\mathrm{n} / \mathrm{a}$ & $x$ & $x$ & $x$ & $x$ \\
\hline SUBTOTAL OF IMPROVING METRICS & $x$ & & $\mathbf{x}$ & $\mathbf{x}$ & $\mathbf{x}$ \\
\hline Operational Efficiency & & & & & \\
\hline
\end{tabular}

To Be Determined

The Board of Governors will work with Universities to develop metrics associated with Operational Efficiencies.

\section{Return on Investment}

\section{Total Research Expenditures (\$M)}

(includes non-Science \& Engineering disciplines)

Science \& Engineering Research Expenditures (\$M)

Percent of Research Expenditures funded from External Sources

\section{Patents Issued}

\section{Licenses/Options Executed}

Licensing Income Received (\$M)

Number of Start-up Companies

Science \& Engineering R\&D Expenditures in Non-Medical/Health Sciences

National Rank is Higher than Predicted by the Financial Resources Ranking (based on U.S. News \& World Report)

Research Doctoral Degrees Awarded Professional Doctoral Degrees Awarded SUBTOTAL OF IMPROVING METRICS TOTAL OF IMPROVING METRICS

\begin{tabular}{|c|c|c|c|c|}
\hline$\% \Delta$ & $\$ x x . x$ & $\$ x x . x$ & $\$ x x . x$ & $\$ x x . x$ \\
\hline$\% \Delta$ & $\$ x X . X$ & $\$ x x . x$ & $\$ x x . x$ & $\$ x x . x$ \\
\hline$\% \Delta$ & $\mathrm{X} \%$ & $\mathrm{X} \%$ & $\mathrm{X} \%$ & $X \%$ \\
\hline$\% \Delta$ & $x$ & $x$ & $x$ & $x$ \\
\hline$\% \Delta$ & $x$ & $x$ & $x$ & $x$ \\
\hline$\% \Delta$ & $\$ x . x$ & $\$ x . x$ & $\$ x . x$ & $\$ x . x$ \\
\hline$\% \Delta$ & $x$ & $x$ & $x$ & $x$ \\
\hline$\% \Delta$ & $x x$ & $x x$ & $x x$ & $x x$ \\
\hline $\mathrm{n} / \mathrm{a}$ & NR-FR & $\mathrm{n} / \mathrm{a}$ & $\mathrm{n} / \mathrm{a}$ & $\mathrm{n} / \mathrm{a}$ \\
\hline$\% \Delta$ & $x x$ & $x x$ & $x x$ & $x x$ \\
\hline$\% \Delta$ & $x x$ & $x x$ & $x x$ & $x x$ \\
\hline $\mathbf{x}$ & & $x$ & $x$ & $x$ \\
\hline$x$ & & $x$ & $x$ & $x$ \\
\hline
\end{tabular}

Notes: (1) the most recent faculty Awards data is based on 2009-10 data. 


\section{KEY PERFORMANCE INDICATORS}

\section{Institution Specific Goals}

Each university will select three metric goals from the following list of metrics included in the 2012-2025 System Strategic Plan:

\begin{tabular}{l} 
Freshman in Top 10\% of Graduating High School Class \\
\hline Percentage of Eligible Programs with Specialized Accreditation \\
\hline Average Time to Degree for FTICs \\
\hline Bachelor's Degrees Awarded to Minorities \\
\hline Number of Adult (age 25+) Undergraduates Enrolled \\
\hline Percent of Course Sections Offered via Distance and Blended \\
Learning
\end{tabular}

\section{Bachelor's Degrees in Areas of Strategic Emphasis \\ Graduate Degrees in Areas of Strategic Emphasis Number of Faculty Designated a Highly Cited Scholar Seek and/or Maintain Carnegie's Community Engagement Classification (narrative goal) \\ Percentage of Students Participating in Identified Community and Business Engagement Activities \\ Enrollment in Professional Training and Continuing Education Courses}

\begin{tabular}{lccccc} 
& $\begin{array}{c}\text { 5 YEAR } \\
\text { TREND } \\
\text { (205-06 to } \\
\text { 2010-11) }\end{array}$ & $\begin{array}{c}\text { 2010-11 } \\
\text { ACTUAL }\end{array}$ & $\begin{array}{c}\text { 2011-12 } \\
\text { ESTIMATES }\end{array}$ & $\begin{array}{c}\text { 2012-13 } \\
\text { GOALS }\end{array}$ & $\begin{array}{c}\text { 3 YEAR } \\
\text { GOALS } \\
\text { (2014-15) }\end{array}$ \\
\hline $\begin{array}{l}\text { Metric 1. Number of Adult (age 25+) } \\
\text { Undergraduates Enrolled }\end{array}$ & $1 \%$ & 888 & 954 & 997 & 1,089 \\
$\begin{array}{l}\text { Metric 2. Percent of Course Sections Offered via } \\
\text { Distance and Blended Learning }\end{array}$ & $33 \%$ & $38 \%$ & $39 \%$ & $40 \%$ & $40 \%$ \\
\hline $\begin{array}{l}\text { Metric 3. Seek and/or Maintain Carnegie's } \\
\text { Community Engagement Classification (narrative } \\
\text { goal) }\end{array}$ & $\begin{array}{l}\text { USFSM will register to receive the Elective Community Engagement } \\
\text { Classification between January 2013 and May 2013, the next open } \\
\text { registration period. According to the Carnegie Foundation timeline, this } \\
\text { would allow for designation in January 2015. }\end{array}$
\end{tabular}

To further distinguish the university's distinctive mission, the university may choose to provide two additional narrative and metric goals that are based on the university's own strategic plan.

Goal 1. Student Access: Expand access to University education that benefits students and the local, national, and global community.

Metric: Citizens Served

$42 \%$

4,604

4,507

4,700

5,100

Goal 2. Student Success: Enhance success of student outcomes, faculty productivity, and community impact.

$\begin{array}{llllll}\text { Metric: AA Graduation Rates } 4 \mathrm{yr} & -4 \%^{*} & 56 \% & 60 \% & 62 \% & 64 \%\end{array}$

* In Fall 2009, USF Tampa mandated that any USFSM student in degree programs hosted by USF Tampa or not offered completely by USFSM be removed from USFSM Home Campus enrollment numbers. As a result of the mandate, USFSM graduation and retention rates were negatively affected. 


\section{OPERATIONS}




\section{FISCAL INFORMATION}

University Revenues (in Millions of Dollars)

\begin{tabular}{ccccccc} 
& $\begin{array}{c}2007-08 \\
\text { Actual }\end{array}$ & $\begin{array}{c}2008-09 \\
\text { Actual }\end{array}$ & $\begin{array}{c}2009-10 \\
\text { Actual }\end{array}$ & $\begin{array}{c}2010-11 \\
\text { Actual }\end{array}$ & $\begin{array}{c}2011-12 \\
\text { Actual }\end{array}$ & $\begin{array}{c}2012-13 \\
\text { Appropriations }\end{array}$ \\
\hline Education \& General - Main Operations & & & & & \\
\hline State Funds & $\$ 15.1$ & $\$ 14.1$ & $\$ 13.1$ & $\$ 12.9$ & $\$ 11.2$ & $\$ 10.1$ \\
\hline Tuition & $\$ 4.2$ & $\$ 4.8$ & $\$ 5.4$ & $\$ 6.3$ & $\$ 6.9$ & $\mathrm{n} / \mathrm{a}$ \\
\hline TOTAL MAIN OPERATIONS & $\$ 19.3$ & $\$ 18.9$ & $\$ 18.5$ & $\$ 19.2$ & $\$ 18.1$ & $\$ 10.1$ \\
\hline $\begin{array}{c}\text { EDUCATION \& GENERAL } \\
\text { TOTAL REVENUES }\end{array}$ & $\$ 19.3$ & $\$ 18.9$ & $\$ 18.5$ & $\$ 19.2$ & $\$ 18.1$ & $\mathrm{n} / \mathrm{a}$ \\
\hline
\end{tabular}

Note: State funds include General Revenue funds, Lottery funds, Federal Stimulus funds, and Phosphate Research funds (for Polytechnic) appropriated by the Florida Legislature (as reported in the Annual Accountability Report). Actual tuition includes base tuition and tuition differential fee revenues for resident and non-resident undergraduate and graduate students net of waivers (as reported in the Annual Accountability Report). Actual tuition revenues are not yet available for the 2012-13 year.

\section{OTHER BUDGET ENTITIES}

\section{Auxiliary Enterprises}

Resources associated with auxiliary units that are self-supporting through fees, payments and charges. Examples include housing, food services, bookstores, parking services, health centers.
Revenues
Data reported at the USF System level.

\section{Contracts \& Grants}

Resources received from federal, state or private sources for the purposes of conducting research and public service activities.
Revenues
Data reported at the USF System level.

\section{Local Funds}

Resources associated with student activity (supported by the student activity fee), student financial aid, concessions, intercollegiate athletics, technology fee, green fee, and student life \& services fee.
Revenues
Data reported at the USF System level.

\section{Faculty Practice Plans}

Revenues/receipts are funds generated from faculty practice plan activities.

\section{Revenues}

\section{OTHER BUDGET ENTITY}

TOTAL REVENUES

UNIVERSITY REVENUES

GRAND TOTAL
Data reported at the USF System level.

Data reported at the USF System level.

Data reported at the USF System level. 


\section{FISCAL INFORMATION (continued)}

Undergraduate Resident Tuition Summary (for 30 credit hours)

\begin{tabular}{lccccc} 
& $\begin{array}{c}\text { FY 2010-11 } \\
\text { ACTUAL }\end{array}$ & $\begin{array}{c}\text { FY 2011-12 } \\
\text { ACTUAL }\end{array}$ & $\begin{array}{c}\text { FY 2012-13 } \\
\text { REQUEST }\end{array}$ & $\begin{array}{c}\text { FY 2013-14 } \\
\text { PLANNED }\end{array}$ & $\begin{array}{c}\text { FY 2014-15 } \\
\text { PLANNED }\end{array}$ \\
\hline Base Tuition & $\$ 2,870$ & $\$ 3,100$ & $\$ 3,100$ & $\$ 3,100$ & $\$ 3,100$ \\
\hline Tuition Differential Fee & $\$ 384$ & $\$ 643$ & $\$ 1,054$ & $\$ 1,677$ & $\$ 2,393$ \\
\hline Percent Increase & $15 \%$ & $15 \%$ & $11 \%$ & $15 \%$ & $15 \%$ \\
\hline Required Fees $^{1}$ & $\$ 1,293$ & $\$ 1,316$ & $\$ 1,376$ & $\$ 1,376$ & $\$ 1,376$ \\
\hline TOTAL TUITION AND FEES & $\$ 4,547$ & $\$ 5,059$ & $\$ 5,530$ & $\$ 6,153$ & $\$ 6,869$
\end{tabular}

Note 1: For more information regarding required fees see list of per credit hour fees and block fees on page 16.

\section{Student Debt Summary}

\begin{tabular}{lccccc} 
& $\begin{array}{c}2007-08 \\
\text { ACTUAL }\end{array}$ & $\begin{array}{c}2008-09 \\
\text { ACTUAL }\end{array}$ & $\begin{array}{c}2009-10 \\
\text { ACTUAL }\end{array}$ & $\begin{array}{c}2010-11 \\
\text { ACTUAL }\end{array}$ & $\begin{array}{c}2011-12 \\
\text { ESTIMATE }\end{array}$ \\
\hline Percent of Bachelor's Recipients with Debt & $\mathrm{n} / \mathrm{a}$ & $\mathrm{n} / \mathrm{a}$ & $\mathrm{n} / \mathrm{a}$ & $\mathrm{n} / \mathrm{a}$ & $\mathrm{n} / \mathrm{a}$ \\
\hline $\begin{array}{l}\text { Average Amount of Debt } \\
\text { for Bachelor's who have graduated with debt }\end{array}$ & $\mathrm{n} / \mathrm{a}$ & $\mathrm{n} / \mathrm{a}$ & $\mathrm{n} / \mathrm{a}$ & $\mathrm{n} / \mathrm{a}$ & $\mathrm{n} / \mathrm{a}$ \\
$\begin{array}{l}\text { Student Loan Cohort Default Rate (2nd Year) } \\
\text { Student Loan Cohort Default Rate (3rd Year) }\end{array}$ & $4.9 \%$ & $6.3 \%$ & $7.0 \%$ & $\mathrm{n} / \mathrm{a}$ & $\mathrm{n} / \mathrm{a}$ \\
\hline
\end{tabular}

Note: Student Loan cohort default data includes undergraduate and graduate students.

Cost of Attendance (for Full-Time Undergraduate Florida Residents in the Fall and Spring of 2011-12)

\begin{tabular}{ccccccc} 
& $\begin{array}{c}\text { TUITION } \\
\& \text { FEES }\end{array}$ & $\begin{array}{c}\text { BOOKS } \& \\
\text { SUPPLIES }\end{array}$ & $\begin{array}{c}\text { ROOM } \\
\& \text { BOARD }\end{array}$ & TRANSPORTATION & $\begin{array}{c}\text { OTHER } \\
\text { EXPENSES }\end{array}$ & TOTAL \\
\hline ON-CAMPUS & $\$ 5,060$ & $\$ 1,500$ & $\$ 9,190$ & $\$ 1,600$ & $\$ 2,500$ & $\$ 19,850$ \\
\hline AT HOME & $\$ 5,060$ & $\$ 1,500$ & $\$ 4,590$ & $\$ 1,600$ & $\$ 2,500$ & $\$ 15,250$ \\
\hline
\end{tabular}

Estimated Net Cost by Family Income (for Full-Time Undergraduate Florida Residents in the Fall and Spring of 2011-12)

\begin{tabular}{|c|c|c|c|c|c|c|}
\hline \multirow{2}{*}{$\begin{array}{l}\text { FAMILY } \\
\text { INCOME } \\
\text { GROUPS }\end{array}$} & \multicolumn{2}{|c|}{$\begin{array}{l}\text { FULL-TIME RESIDENT } \\
\text { UNDERGRADUATES }\end{array}$} & \multirow{2}{*}{$\begin{array}{c}\text { AVG. NET } \\
\text { COST OF } \\
\text { ATTENDANCE }\end{array}$} & \multirow{2}{*}{$\begin{array}{c}\text { AVG. NET } \\
\text { TUITION } \\
\text { \& FEES } \\
\end{array}$} & \multirow{2}{*}{$\begin{array}{l}\text { AVERAGE } \\
\text { GIFT AID } \\
\text { AMOUNT }\end{array}$} & \multirow{2}{*}{$\begin{array}{l}\text { AVERAGE } \\
\text { LOAN } \\
\text { AMOUNT }\end{array}$} \\
\hline & HEADCOUNT & PERCENT & & & & \\
\hline Below $\$ 40,000$ & 278 & $57 \%$ & $\$ 12,737$ & $-\$ 1,970$ & $\$ 6,459$ & $\$ 5,683$ \\
\hline$\$ 40,000-\$ 59,999$ & 56 & $11 \%$ & $\$ 14,756$ & $\$ 922$ & $\$ 3,593$ & $\$ 4,337$ \\
\hline$\$ 60,000-\$ 79,999$ & 34 & $7 \%$ & $\$ 15,780$ & $\$ 2,641$ & $\$ 2,041$ & $\$ 4,435$ \\
\hline$\$ 80,000-\$ 99,999$ & 30 & $6 \%$ & $\$ 14,772$ & $\$ 3,095$ & $\$ 1,508$ & $\$ 3,966$ \\
\hline$\$ 100,000$ Above & 42 & $9 \%$ & $\$ 15,207$ & $\$ 2,824$ & $\$ 1,750$ & $\$ 1,954$ \\
\hline Missing & 50 & $10 \%$ & $\$ 15,226$ & $\$ 4,613$ & $\$ 11$ & $\$ 100$ \\
\hline TOTAL & 490 & $100 \%$ & $\$ 13,769$ & $\$ 73$ & $\$ 4,460$ & $\$ 4,448$ \\
\hline
\end{tabular}

Notes: This data only represents Fall and Spring financial aid data, and is accurate as of March 31, 2012. Please note that small changes to Spring 2012 awards are possible before the data is finalized. Family Income Groups are based on the Total Family Income (including untaxed income) as reported on student FAFSA records. Full-time Students is a headcount based on at least 24 credit hours during Fall and Spring terms. Average Gift Aid includes all grants and scholarships from Federal, State, University and other private sources administered by the Financial Aid Office. Student waivers are also included in the Gift Aid amount. Gift Aid does not include the parental contribution towards EFC. Net Cost of Attendance is the actual average of the total Costs of Attendance (which will vary by income group due to the diversity of students living on- \& off- campus) minus the average Gift Aid amount. Net Tuition \& Fees is the actual average of the total costs of tuition and fees (which will vary by income group due to the amount of credit hours students are enrolled) minus the average Gift Aid amount (see page 16 for list of fees that are included). Average Loan Amount includes Federal (Perkins, Stafford, Ford Direct, and PLUS loans) and all private loans. The bottom-line Average represents the average of all full-time undergraduate Florida residents. 


\section{FISCAL INFORMATION (continued) TUITION DIFFERENTIAL FEE REQUEST FOR 2012-13}

\begin{tabular}{|l|l|}
\hline & \multicolumn{2}{|c|}{ Effective Date } \\
\hline University Board of Trustees Approval Date: & $6 / 14 / 2012$ \\
\hline Implementation Date (month/year): & August 2012 \\
\hline
\end{tabular}

Campus or Center Location

Campus or Center Location to which the Tuition Differential fee will apply (If the entire university, indicate as such):

USF Sarasota-Manatee

Undergraduate Course(s)

Course(s). (If the tuition differential fee applies to all university $\quad$ All university undergraduate courses.

undergraduate courses, indicate as such. If not, also provide a

rationale for the differentiation among courses):

Current and Proposed Increase in the Tuition Differential Fee

Current Undergraduate Tuition Differential per credit hour:

Percentage tuition differential fee increase (calculated as a percentage of the sum of base tuition plus tuition differential):

$\$$ Increase in tuition differential per credit hour: $\$ 21.42$

$\$$ Increase in tuition differential for 30 credit hours: $11 \%$

$\$ 13.72$

$\$ 411.60$

Projected Differential Revenue Generated

Incremental differential fee revenue generated in 2012-13 (projected) :

Total differential fee revenue generated in 2012-13 (projected): $\quad \$ 1,332,362$

\section{Intended Uses}

Cost-efficient utilization of instructional technology and innovation , along with investments in faculty and professional staff to enhance timely college completion rates, attainment and career placement through activities such as:

- Need-Based Financial Aid (at 40\%): Expand access for students; and accelerated path to graduation. Provide much needed financial support for talented students with limited income as Pell grant funding continues to shrink. More students supported with financial aid scholarships and reduced loan indebtedness.

- Expanding the High Skilled Workforce and Assuring Job Placement, especially in STEM: Expanded STEM and IT programs and degrees awarded; Strengthened relationships with business and industry; Increased number of co-op partnerships; Expanded professional support for job placement through USF's Career Center/Job Hub.

- Academic Advising and Veterans' Support: Enhanced academic advising through technology, focus on goal setting, time-to-degree, improved graduation rates, reducing excess hours, and expanding USF's Veterans' Success program. Improved tracking of students and graduates.

- Financial Counseling and Debt Reduction: Financial impact of the increasing costs of higher education mitigated through focused and proactive financial counseling and debt reduction strategies. Reduced amount of student debt. Reduced number and percentage of students with debt.

\section{Describe the Impact to the Institution if Tuition Differential is Not Approved}

Significant risk and negative impact on progress toward BOG/SUS and BOT/USF strategic goals.USF System efforts to move away from the traditional delivery model will be significantly impaired or delayed, potentially resulting in stagnant or declining graduation rates and a reduced ability to meet the workforce demands of the state. The loss of potential need-based financial aid (40\%) will further reduce student access, retention and graduation rates while likely increasing student indebtedness.

USF's commitment to investing in (60\%) enhanced instruction and learning (particularly in STEM), serving returning veterans, reducing excess hours and student debt, and job placement for graduates will be diminished or, at best, delayed. 


\section{Request to Modify or Waive Tuition Differential Uses}

(this section is applicable only if HB 7135 is signed by the Governor and the university wishes to request a change to the $70 \%$ I $30 \%$ intended uses criteria identified in Regulation 7.001(14))

The University of South Florida System is requesting permission to change the intended use criteria for tuition differential uses, identified in Regulation 7.001(14), for academic year 2012-2013 from 70\%/30\% to 60\%/40\%. The proportion of Pell eligible students at USF now exceeds $40 \%$, and with declining federal aid, the institution believes that this is a worthwhile investment to ensure timely completion of degrees and reduced student indebtedness. 


\section{FISCAL INFORMATION (continued) TUITION DIFFERENTIAL SUPPLEMENTAL INFORMATION}

Provide the following information for the 2011-12 academic year.

\begin{tabular}{|c|c|}
\hline $\begin{array}{l}2011-2012-70 \% \text { Initiatives (list the initiatives provided in } \\
\text { the } 2011-12 \text { tuition differential request) }\end{array}$ & University Update on Each Initiative \\
\hline Increase undergraduate course offerings. & $\begin{array}{l}182 \text { course sections were funded partially or fully through the } \\
\text { tuition differential. }\end{array}$ \\
\hline \multicolumn{2}{|c|}{ Additional Detail, where applicable: } \\
\hline $\begin{array}{l}\text { Total Number of Faculty Hired or Retained (funded by tuition } \\
\text { differential): }\end{array}$ & 87 \\
\hline $\begin{array}{l}\text { Total Number of Advisors Hired or Retained (funded by } \\
\text { tuition differential): }\end{array}$ & 0 \\
\hline $\begin{array}{l}\text { Total Number of Course Sections Added or Saved (funded } \\
\text { by tuition differential): }\end{array}$ & 182 \\
\hline $\begin{array}{c}2011-2012-30 \% \text { Initiatives (list the initiatives provided in } \\
\text { the } 2011-12 \text { tuition differential request) }\end{array}$ & University Update on Each Initiative \\
\hline $\begin{array}{l}\text { Increase the number of students who are awarded grants } \\
\text { funded by the tuition differential. }\end{array}$ & $\begin{array}{l}\text { We were able to increase the number of students paid by } 128 \text {, } \\
\text { or } 93.4 \% \text {. }\end{array}$ \\
\hline $\begin{array}{l}\text { Increase the average amount of awards in order to partially } \\
\text { off-set tuition increases for needy students. }\end{array}$ & $\begin{array}{l}\text { The average award increased by } \$ 261 \text {, which represents an } \\
\text { increase of } 33.5 \% \text {. }\end{array}$ \\
\hline \multicolumn{2}{|c|}{ Additional Information (estimates as of April 30, 2012): } \\
\hline $\begin{array}{l}\text { Unduplicated Count of Students Receiving at least one } \\
\text { Tuition Differential-Funded Award: }\end{array}$ & 265 \\
\hline $\begin{array}{l}\text { \$ Mean (per student receiving an award) of Tuition } \\
\text { Differential-Funded Awards: }\end{array}$ & 1044 \\
\hline $\begin{array}{l}\text { \$ Minimum (per student receiving an award) of Tuition } \\
\text { Differential-Funded Awards: }\end{array}$ & 188 \\
\hline $\begin{array}{l}\text { \$ Maximum (per student receiving an award) of Tuition } \\
\text { Differential-Funded Awards: }\end{array}$ & 2500 \\
\hline
\end{tabular}




\section{FISCAL INFORMATION (continued) TUITION DIFFERENTIAL COLLECTIONS, EXPENDITURES, \& AVAILABLE BALANCES - FISCAL YEAR 2011-12 AND 2012-13}

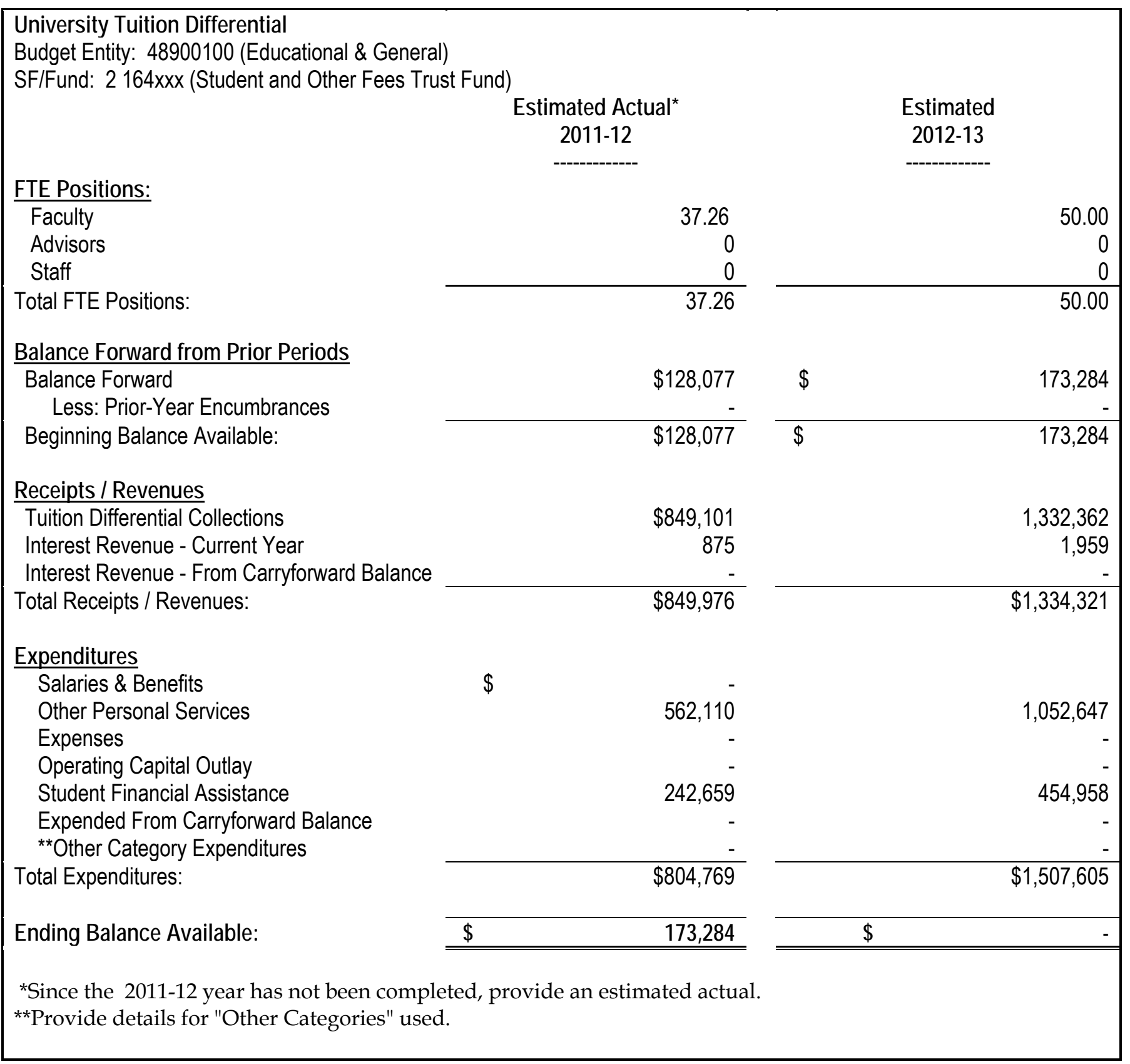




\section{FISCAL INFORMATION (continued) UNIVERSTYY TUITION, FEES AND HOUSING PROJ ECTIONS}

\section{University of South Forida- Sarasota-Manatee}

\begin{tabular}{|c|c|c|c|c|c|c|c|}
\hline \multirow[t]{2}{*}{ Undergraduate Students } & \multicolumn{3}{|c|}{ Actual__L } & \multicolumn{4}{|c|}{ Projected- } \\
\hline & 2009-10 & $2010-11$ & 2011-12 & 2012-13 & 2013-14 & 201415 & 2015-16 \\
\hline \multicolumn{8}{|l|}{ Tuition: } \\
\hline Base Tution- ( $0 \%$ projected legislative & $\$ 88.59$ & $\$ 95.67$ & $\$ 103.32$ & $\$ 103.32$ & $\$ 103.32$ & $\$ 103.32$ & $\$ 103.32$ \\
\hline TutionDifferertial (nomorethan 15\%) & $\$ 5.74$ & $\$ 1280$ & $\$ 21.42$ & $\$ 35.14$ & $\$ 55.90$ & $\$ 79.78$ & $\$ 107.24$ \\
\hline Total Base Tuitionand Differential & $\$ 94.33$ & $\$ 108.47$ & $\$ 124.74$ & $\$ 138.46$ & $\$ 159.22$ & $\$ 183.10$ & $\$ 210.56$ \\
\hline \%Change & & $15.0 \%$ & $15.0 \%$ & $11.0 \%$ & $15.0 \%$ & $15.0 \%$ & $15.0 \%$ \\
\hline \multicolumn{8}{|l|}{ Fees (per credt hour): } \\
\hline Studert Financial Aid ${ }^{1}$ & $\$ 4.42$ & $\$ 4.78$ & $\$ 5.16$ & $\$ 5.16$ & $\$ 5.16$ & $\$ 5.16$ & $\$ 5.16$ \\
\hline Building/Capital Improvement ${ }^{2}$ & $\$ 4.76$ & $\$ 4.76$ & $\$ 4.76$ & $\$ 6.76$ & $\$ 6.76$ & $\$ 6.76$ & $\$ 6.76$ \\
\hline Adivity\&Senice & $\$ 9.82$ & $\$ 20.19$ & $\$ 20.19$ & $\$ 20.19$ & $\$ 20.19$ & $\$ 20.19$ & $\$ 20.19$ \\
\hline Health & $\$ 200$ & $\$ 4.03$ & $\$ 4.03$ & $\$ 4.03$ & $\$ 4.03$ & $\$ 4.03$ & $\$ 4.03$ \\
\hline Athletic & $\$ 210$ & $\$ 4.23$ & $\$ 4.23$ & $\$ 4.23$ & $\$ 4.23$ & $\$ 4.23$ & $\$ 4.23$ \\
\hline \multicolumn{8}{|l|}{ TransportationAccess } \\
\hline Tedmology 1 & $\$ 4.42$ & $\$ 4.78$ & $\$ 5.16$ & $\$ 5.16$ & $\$ 5.16$ & $\$ 5.16$ & $\$ 5.16$ \\
\hline Sub total (credit hour fees) & $\$ 27.52$ & $\$ 4277$ & $\$ 43.53$ & $\$ 45.53$ & $\$ 45.53$ & $\$ 45.53$ & $\$ 45.53$ \\
\hline Total Tuition and Fees per credit ho & $\$ 121.85$ & $\$ 151.24$ & $\$ 168.27$ & $\$ 183.99$ & $\$ 204.75$ & $\$ 228.63$ & $\$ 256.09$ \\
\hline \%Change & & $24.1 \%$ & $11.3 \%$ & $9.3 \%$ & $11.3 \%$ & $11.7 \%$ & $120 \%$ \\
\hline \multicolumn{8}{|l|}{ Fees(blockper tem): } \\
\hline \multicolumn{8}{|l|}{ Adtivity\&Serviœ } \\
\hline \multicolumn{8}{|l|}{ Health } \\
\hline Athletic & $\$ 5.00$ & $\$ 5.00$ & $\$ 5.00$ & $\$ 5.00$ & $\$ 5.00$ & $\$ 5.00$ & $\$ 5.00$ \\
\hline \multicolumn{8}{|l|}{ TransportationAccess } \\
\hline Total BlockFees per term & $\$ 5.00$ & $\$ 5.00$ & $\$ 5.00$ & $\$ 5.00$ & $\$ 5.00$ & $\$ 5.00$ & $\$ 5.00$ \\
\hline \%Change & & $0.0 \%$ & $0.0 \%$ & $0.0 \%$ & $0.0 \%$ & $0.0 \%$ & $0.0 \%$ \\
\hline Total Tuition for 30 Credit Hours & $\$ 2,829.90$ & $\$ 3,254.10$ & $\$ 3,74231$ & $\$ 4,153.91$ & $\$ 4,776.71$ & $\$ 5,493.11$ & $\$ 6,316.91$ \\
\hline Total Fees for 30 Credit Hours & $\$ 835.60$ & $\$ 1,293.10$ & $\$ 1,315.90$ & $\$ 1,375.90$ & $\$ 1,375.90$ & $\$ 1,375.90$ & $\$ 1,375.90$ \\
\hline Total Tuition and Fees for 30 Credit & $\$ 3,665.50$ & $\$ 4,547.20$ & $\$ 5,058.21$ & $\$ 5,529.81$ & $\$ 6,15261$ & $\$ 6,869.01$ & $\$ 7,69281$ \\
\hline \$Change & & $\$ 881.70$ & $\$ 51101$ & $\$ 47160$ & $\$ 62280$ & $\$ 716.40$ & $\$ 823.80$ \\
\hline \%Change & & $24.1 \%$ & $11.2 \%$ & $9.3 \%$ & $113 \%$ & $116 \%$ & $120 \%$ \\
\hline \multicolumn{8}{|l|}{ at-of-StateFees } \\
\hline Ot-of-State Undergraduate Fee & $\$ 343.16$ & $\$ 343.16$ & $\$ 291.68$ & $\$ 315.00$ & $\$ 315.00$ & $\$ 315.00$ & $\$ 315.00$ \\
\hline Ot-of-State Undergraduate Studert Fi & $\$ 17.15$ & $\$ 17.15$ & $\$ 14.58$ & $\$ 15.75$ & $\$ 15.75$ & $\$ 15.75$ & $\$ 15.75$ \\
\hline Total per credit hour & $\$ 360.31$ & $\$ 360.31$ & $\$ 306.26$ & $\$ 330.75$ & $\$ 330.75$ & $\$ 330.75$ & $\$ 330.75$ \\
\hline \%Change & & $0 \%$ & $-15 \%$ & $8 \%$ & $0 \%$ & $0 \%$ & $0 \%$ \\
\hline Total Tuition for 30 Credit Hours & $\$ 2,829.90$ & $\$ 3,254.10$ & $\$ 3,74231$ & $\$ 4,153.91$ & $\$ 4,766.71$ & $\$ 5,493.11$ & $\$ 6,316.91$ \\
\hline Total Fees for 30 Credit Hours & $\$ 11,644,90$ & $\$ 12,10240$ & $\$ 10,503.70$ & $\$ 11,298.40$ & $\$ 11,298.40$ & $\$ 11,298.40$ & $\$ 11,298.40$ \\
\hline Total Tuition and Fees for 30 Credit & $\$ 14,474,80$ & $\$ 15,356.50$ & $\$ 14,246.01$ & $\$ 15,45231$ & $\$ 16,075.11$ & $\$ 16,79151$ & $\$ 17,615.31$ \\
\hline \$Change & & $\$ 881.70$ & $\$ 1,110,49$ & $\$ 1,206.30$ & $\$ 62280$ & $\$ 716.40$ & $\$ 823.80$ \\
\hline$\%$ Change & & $6.1 \%$ & $-7.2 \%$ & $8.5 \%$ & $4.0 \%$ & $4.5 \%$ & $4.9 \%$ \\
\hline
\end{tabular}




\section{ENROLLMENT PLANNING}

Planned Growth by Student Type (for E\&G students at all campuses)

\begin{tabular}{|c|c|c|c|c|c|c|c|c|c|}
\hline \multirow{2}{*}{$\begin{array}{l}\text { UNDERGRADUATE } \\
\text { UNA }\end{array}$} & \multirow[t]{2}{*}{$\begin{array}{l}5 \text { YEAR } \\
\text { TREND } \\
\text { (2005-06 to } \\
\text { 2010-11) }\end{array}$} & \multicolumn{2}{|c|}{$\begin{array}{c}2010-11 \\
\text { ACTUAL } \\
\text { HEADCOUNT }\end{array}$} & \multicolumn{2}{|c|}{$\begin{array}{c}2012-13 \\
\text { PLANNED } \\
\text { HEADCOUNT }\end{array}$} & \multicolumn{2}{|c|}{$\begin{array}{c}2013-14 \\
\text { PLANNED } \\
\text { HEADCOUNT }\end{array}$} & \multicolumn{2}{|c|}{$\begin{array}{c}3 \text { YEAR } \\
\text { (2014-15) } \\
\text { PLANNED } \\
\text { HEADCOUNT }\end{array}$} \\
\hline & & & & & & & & & \\
\hline FTIC (Regular Admit) & $\mathrm{n} / \mathrm{a}$ & 0 & $n / a$ & 0 & $x x \%$ & 95 & $5 \%$ & 152 & $8 \%$ \\
\hline FTIC (Profile Admit) & $\mathrm{n} / \mathrm{a}$ & 0 & $n / a$ & 0 & $x x \%$ & 5 & $0 \%$ & 8 & $0 \%$ \\
\hline AA Transfers* & $32 \%$ & 1,133 & $74 \%$ & 1,235 & $75 \%$ & 1,291 & $71 \%$ & 1,349 & $69 \%$ \\
\hline Other Transfers & $5 \%$ & 400 & $26 \%$ & 418 & $25 \%$ & 437 & $24 \%$ & 456 & $23 \%$ \\
\hline Subtotal & $24 \%$ & 1,533 & $100 \%$ & 1,653 & $100 \%$ & 1,828 & $100 \%$ & 1,965 & $100 \%$ \\
\hline \multicolumn{10}{|l|}{ GRADUATE STUDENTS } \\
\hline Master's & $-38 \%$ & 184 & $100 \%$ & 130 & $100 \%$ & 136 & $100 \%$ & 142 & $100 \%$ \\
\hline Research Doctoral & $-100 \%$ & 0 & $0 \%$ & 0 & $0 \%$ & 0 & $x x \%$ & 0 & $0 \%$ \\
\hline Professional Doctoral & $\mathrm{n} / \mathrm{a}$ & 0 & $0 \%$ & 0 & $0 \%$ & 0 & $x x \%$ & 0 & $0 \%$ \\
\hline Subtotal & $-39 \%$ & 184 & $100 \%$ & 130 & $100 \%$ & 136 & $100 \%$ & 142 & $100 \%$ \\
\hline NOT-DEGREE SEEKING & $38 \%$ & 180 & & 162 & & 169 & & 177 & \\
\hline MEDICAL & $\mathrm{n} / \mathrm{a}$ & $\mathrm{n} / \mathrm{a}$ & & 0 & & 0 & & 0 & \\
\hline TOTAL & $14 \%$ & 1,897 & & 1,945 & & 2,133 & & 2,284 & \\
\hline
\end{tabular}

Note*: AA transfers refer only to transfers from the Florida College System.

Planned Growth by Method of Instruction (for E\&G students at all campuses)

\begin{tabular}{|c|c|c|c|c|c|c|c|c|c|}
\hline & \multirow{2}{*}{$\begin{array}{c}5 \text { YEAR } \\
\text { TREND } \\
\text { (2005-06 to } \\
\text { 2010-11) }\end{array}$} & \multicolumn{2}{|c|}{ 2010-11 } & \multicolumn{2}{|c|}{$2012-13$} & \multicolumn{2}{|c|}{ 2013-14 } & \multicolumn{2}{|c|}{$\begin{array}{c}3 \text { YEAR } \\
(2014-15)\end{array}$} \\
\hline & & $\begin{array}{l}\text { ACTUAL } \\
\text { FTE }\end{array}$ & $\begin{array}{c}\% \text { of } \\
\text { TOTAL }\end{array}$ & $\begin{array}{l}\text { PLANNED } \\
\text { FTE }\end{array}$ & $\begin{array}{c}\% \text { of } \\
\text { TOTAL }\end{array}$ & $\begin{array}{l}\text { PLANNED } \\
\text { FTE }\end{array}$ & $\begin{array}{c}\% \text { of } \\
\text { TOTAL }\end{array}$ & $\begin{array}{l}\text { PLANNED } \\
\text { FTE }\end{array}$ & $\begin{array}{l}\% \text { of } \\
\text { TOTAL }\end{array}$ \\
\hline \multicolumn{10}{|l|}{ UNDERGRADUATE } \\
\hline DISTANCE $(>80 \%$ & $283 \%$ & 467 & $44 \%$ & 536 & $45 \%$ & 570 & $45 \%$ & 615 & $46 \%$ \\
\hline HYBRID (50\%-79\%) & $\%$ & 27 & $2 \%$ & 36 & $3 \%$ & 38 & $3 \%$ & 40 & $3 \%$ \\
\hline TRADITIONAL (<50\%) & $-2 \%$ & 576 & $54 \%$ & 619 & $52 \%$ & 659 & $52 \%$ & 681 & $51 \%$ \\
\hline TOTAL & $51 \%$ & 1070 & $100 \%$ & 1191 & $100 \%$ & 1267 & $100 \%$ & 1336 & $100 \%$ \\
\hline \multicolumn{10}{|l|}{ GRADUATE } \\
\hline DISTANCE $(80 \%)$ & $19792 \%$ & 24 & $19 \%$ & 20 & $18 \%$ & 21 & $18 \%$ & 22 & $18 \%$ \\
\hline HYBRID (50\%-79\%) & $\% \Delta$ & 2.5 & $2 \%$ & 3 & $3 \%$ & 3 & $3 \%$ & 6 & $5 \%$ \\
\hline TRADITIONAL (<50\%) & $-37 \%$ & 100.5 & $79 \%$ & 87 & $79 \%$ & 91 & $79 \%$ & 92 & $77 \%$ \\
\hline TOTAL & $-20 \%$ & 127 & $100 \%$ & 110 & $100 \%$ & 115 & $100 \%$ & 120 & $100 \%$ \\
\hline
\end{tabular}

Note: Full-time Equivalent (FTE) student is a measure of instructional effort (and student activity) that is based on the number of credit hours that students enroll. FTE is based on the Florida definition, which divides undergraduate credit hours by 40 and graduate credit hours by 32 . Distance Learning is a course in which at least 80 percent of the direct instruction of the course is delivered using some form of technology when the student and instructor are separated by time or space, or both (per 1009.24(17), F.S.). Hybrid is a course where $50 \%$ to $79 \%$ of the instruction is delivered using some form of technology, when the student and instructor are separated by time or space, or both (per SUDS data element 2052). Traditional (and Technology

Enhanced) refers to primarily face to face instruction utilizing some form of technology for delivery of supplemental course materials for no more than $49 \%$ of instruction (per SUDS data element 2052). 


\section{ENROLLMENT PLANNING (continued)}

Statutorily Required Enrollment Plan (Based on State-Fundable Florida FTE)

\begin{tabular}{|c|c|c|c|c|c|c|c|c|}
\hline & $\begin{array}{l}\text { Funded } \\
2011-12\end{array}$ & $\begin{array}{c}\text { Estimated } \\
2011-12\end{array}$ & $\begin{array}{l}\text { Funded } \\
2012-13\end{array}$ & $\begin{array}{l}\text { Planned } \\
2012-13\end{array}$ & $\begin{array}{l}\text { Planned } \\
\text { 2013-14 }\end{array}$ & $\begin{array}{l}3 \text { Year } \\
\text { Planned } \\
2014-15\end{array}$ & $\begin{array}{l}5 \text { Year } \\
\text { Planned } \\
2016-17\end{array}$ & $\begin{array}{c}\text { 5-Year } \\
\text { Projected } \\
\text { Average } \\
\text { Annual } \\
\text { Growth } \\
\text { Rate }\end{array}$ \\
\hline \multicolumn{9}{|l|}{ Florida Resident } \\
\hline LOWER DIVISION & 0 & 107 & 0 & 146 & 175 & 195 & 212 & $9.1 \%$ \\
\hline UPPER DIVISION & 798 & 957 & 798 & 1018 & 1064 & 1112 & 1213 & $3.8 \%$ \\
\hline GRAD I & 182 & 104 & 182 & 105 & 110 & 115 & 125 & $3.8 \%$ \\
\hline GRAD II & 0 & 1 & 0 & 0 & 0 & 0 & 0 & $\%$ \\
\hline TOTAL & 980 & 1169 & 980 & 1269 & 1349 & 1421 & 1551 & $4.5 \%$ \\
\hline \multicolumn{9}{|c|}{ Not a Florida Resident } \\
\hline LOWER DIVISION & 0 & 3 & 0 & 4 & 5 & 5 & 6 & $9.1 \%$ \\
\hline UPPER DIVISION & 0 & 21 & 0 & 22 & 23 & 24 & 27 & $3.8 \%$ \\
\hline GRAD I & 0 & 5 & 0 & 5 & 5 & 5 & 6 & $3.8 \%$ \\
\hline GRAD ॥ & 0 & 0 & 0 & 0 & 0 & 0 & 0 & $\%$ \\
\hline TOTAL & 0 & 30 & 0 & 31 & 33 & 35 & 39 & $4.5 \%$ \\
\hline \multicolumn{9}{|l|}{ TOTAL } \\
\hline LOWER DIVISION & 0 & 110 & 0 & 150 & 180 & 200 & 218 & $9.1 \%$ \\
\hline UPPER DIVISION & 798 & 978 & 798 & 1040 & 1087 & 1136 & 1240 & $3.8 \%$ \\
\hline GRAD I & 182 & 110 & 182 & 110 & 115 & 120 & 131 & $3.8 \%$ \\
\hline GRAD ॥ & 0 & 1 & 0 & 0 & 0 & 0 & 0 & $\%$ \\
\hline TOTAL & 980 & 1199 & 980 & 1300 & 1382 & 1456 & 1590 & $4.5 \%$ \\
\hline $\begin{array}{l}\text { TOTAL } \\
\text { (US FTE) }\end{array}$ & 1306 & 1455 & 1306 & 1733 & 1842 & 1941 & 2119 & $4.5 \%$ \\
\hline
\end{tabular}

Note: Full-time Equivalent (FTE) student is a measure of instructional effort (and student activity) that is based on the number of credit hours that students enroll. FTE is based on the Florida definition, which divides undergraduate credit hours by 40 and graduate credit hours by 32 .

Medical Student Headcounts (FTE does not apply)

\section{Medicine Headcounts}

FLORIDA RESIDENT

NON-RESIDENT

TOTAL 


\section{ACADEMC PROGRAM COORDINATION}

New Programs To Be Considered by University in 2012-13 for Implementation

\begin{tabular}{|c|c|c|c|c|c|c|}
\hline PROGRAM TITLES & $\begin{array}{l}\text { CIP CODE } \\
\text { 6-digit }\end{array}$ & $\begin{array}{c}\text { AREA OF } \\
\text { STRATEGIC } \\
\text { EMPHASIS }\end{array}$ & $\begin{array}{c}\text { OTHER } \\
\text { UNIVERSITIE } \\
\text { S } \\
\text { WITH SAME } \\
\text { PROGRAM }\end{array}$ & $\begin{array}{l}\text { OFFERED } \\
\text { VIA } \\
\text { DISTANCE } \\
\text { LEARNING } \\
\text { IN SYSTEM } \\
\end{array}$ & $\begin{array}{l}\text { PROJECTED } \\
\text { ENROLLMENT } \\
\text { in 5th year }\end{array}$ & $\begin{array}{l}\text { PROPOSED } \\
\text { DATE OF } \\
\text { SUBMISSION } \\
\text { TO UBOT } \\
\end{array}$ \\
\hline \multicolumn{7}{|l|}{ BACHELOR'S PROGRAMS } \\
\hline $\begin{array}{l}\text { B.A. in Business \& Technical } \\
\text { Communication }\end{array}$ & 23.1101 & $\mathrm{~N} / \mathrm{A}$ & None & No & 100 & Oct-12 \\
\hline
\end{tabular}

MASTER'S, SPECIALIST AND OTHER ADVANCED MASTER'S PROGRAMS

\begin{tabular}{lllllll}
\hline M.A. in Education & 13.0101 & N/A & UCF, FAU & Y/N & 50 & Oct-12
\end{tabular}

\section{DOCTORAL PROGRAMS}

New Programs To Be Considered by University in 2013-15 for Implementation

\begin{tabular}{|c|c|c|c|c|c|c|c|c|}
\hline \multirow{2}{*}{$\frac{\text { PROGRAM TITLES }}{\text { BACHELOR'S PROGRAMS }}$} & \multirow[t]{2}{*}{$\begin{array}{l}\text { CIP } \\
\text { CODE } \\
\text { 6-digit }\end{array}$} & \multicolumn{2}{|c|}{$\begin{array}{l}\text { AREA OF } \\
\text { STRATEGIC } \\
\text { EMPHASIS }\end{array}$} & $\begin{array}{l}\text { OTHER } \\
\text { UNIVERSITIES } \\
\text { WITH SAME } \\
\text { PROGRAM }\end{array}$ & \multicolumn{2}{|c|}{$\begin{array}{l}\text { OFFERED VIA } \\
\text { DISTANCE } \\
\text { LEARNING } \\
\text { IN SYSTEM } \\
\end{array}$} & \multirow[t]{2}{*}{$\begin{array}{l}\text { PROJECTED } \\
\text { ENROLLMENT } \\
\text { in } 5 \text { th year }\end{array}$} & \multirow[t]{2}{*}{$\begin{array}{l}\text { PROPOSED } \\
\text { DATE OF } \\
\text { SUBMISSION } \\
\text { TO UBOT } \\
\end{array}$} \\
\hline & & & & & & & & \\
\hline Biology & & 6.0101 & STEM & $\begin{array}{c}\text { FAMU, } \\
\text { FGCU, } \\
\text { UCF, UF } \\
\text { T, USF P } \\
\text { SP, Ul }\end{array}$ & $\begin{array}{l}\text { EAU, } \\
\text { FIU, } \\
\text { USF } \\
\text { USF } \\
\text { NF }\end{array}$ & No & 100 & Oct-2014 \\
\hline Operations Research \& Management & & 2.0205 & $\mathrm{~N} / \mathrm{A}$ & None & & No & 50 & Oct-2014 \\
\hline
\end{tabular}

\section{MASTER'S, SPECIALIST AND OTHER ADVANCED MASTER'S PROGRAMS}

\begin{tabular}{lllclll}
\hline Communication Sciences and Disorders & 51.0201 & N/A & None & Yes & 50 & Oct-2014 \\
Social Science Education & 13.1317 & N/A & FSU, USF T, & No & 40 & Oct-2014
\end{tabular}




\section{KEY PERFORMANCE INDICATOR DEFINITIONS}

\section{Goals Common to All Universities \\ Academic Quality \\ National Ranking for University and Program(s)}

\section{Avg. SAT Score}

\section{Avg. HS GPA (on 4.0 scale)}

\section{Professional/Licensure Exam \\ First-time Pass Rates}

Exams Above National/State Benchmark

Exams Below National/State Benchmark

\section{Percent of Undergraduate Seniors Participating in a Research Course}

\section{Operational Efficiency}

\section{Freshman Retention Rate}

\section{FTIC Graduation Rates \\ In 4 years (or less) \\ In 6 years (or less)}

Describe plans for increasing national preeminence of University and select programs.

The average SAT score for all three subtests (reading, mathematics and writing) for Admitted and Registered FTIC (B,E) students.

The average HS GPA for Admitted and Registered FTIC (B,E) students.

The number of exams with first-time pass rates above and below the national or state average, as reported in the 2010-11 Accountability report, including: Nursing, Law, Medicine (3 subtests), Veterinary, Pharmacy, Dental (2 subtests), Physical Therapy, and Occupational Therapy.

This metric represents the percentage of seniors who enrolled in a Research course during their last year. Board staff will work with University officials during the summer of 2012 to determine a system-wide definition of 'a research course'.

The percentage of a full-time, first-time-in-college (FTIC) undergraduate cohort (entering in fall term or summer continuing to fall) that is still enrolled or has graduated from the same institution in the following fall term.

First-time-in-college (FTIC) cohort is defined as undergraduates entering in fall term (or summer continuing to fall) with fewer than 12 hours earned since high school graduation. The rate is the percentage of the initial cohort that has either graduated or is still enrolled in the fourth or sixth academic year. Both full-time and parttime students are used in the calculation. Note: Students of degree programs longer than four years are included in the cohorts. The initial cohort is revised to remove students, who have allowable exclusions as defined by IPEDS, from the cohort. Students with unreported gender are included.

AA Transfer cohort is defined as undergraduates entering in the fall term (or summer continuing to fall) and having earned an AA degree from an institution in the Florida College System. The rate is the percentage of the initial cohort that has either graduated or is still enrolled in the second or fourth academic year. Both full-time and part-time students are used in the calculation. Note: Students of degree programs longer than four years are included in the cohorts. The initial cohort is revised to remove students, who have allowable exclusions as defined by IPEDS, from the cohort.

The percentage of baccalaureate degrees awarded within $110 \%$ of the hours required for a degree. Excluding students with dual majors, this metric computes total academic credit as a percentage of catalog hours required for the students major (excluding remedial coursework). For the purposes of calculating excess hours, remedial credit hours includes up to 10 foreign language credit hours that are excluded for transfer students in Florida. 
Return on Investment

This is a count of baccalaureate degrees granted. Students who earn two distinct degrees in the same term are counted twice whether their degrees are from the same six-digit CIP code or different CIP codes. Students who earn only one degree are counted once - even if they completed multiple majors or tracks.

Percent of Bachelor's Degrees in STEM

Graduate Degrees Awarded

Percent of Graduate Degrees in STEM

Percent of Baccalaureate Graduates Employed in Florida

Percent of Baccalaureate Graduates Continuing their Education (in FL)

Annual Gifts Received (\$M)

Endowment (\$M)

Goals Specific to Research Universities

Academic Quality

Faculty Awards

National Academy Members

Number of Post-Doctoral appointees
The percentage of baccalaureate degrees that are classified as STEM by the Board of Governors in the SUS program inventory.

This is a count of graduate degrees granted.

The percentage of graduate degrees that are classified as STEM by the Board of Governors in the SUS program inventory.

This is the percentage of baccalaureate graduates with valid social security numbers that are employed in Florida during the Oct-Dec fiscal quarter based on FETPIP data.

This is the percentage of baccalaureate graduates with valid social security numbers that are continuing their education in Florida during the Oct-Dec fiscal quarter based on FETPIP data.

As reported in the Council for Aid to Education's Voluntary Support of Education (VSE) survey in the section entitled "Gift Income Summary," this is the sum of the present value of all gifts (including outright and deferred gifts) received for any purpose and from all sources during the fiscal year, excluding pledges and bequests. (There's a deferred gift calculator at www.cae.org/vse.) The present value of non-cash gifts is defined as the tax deduction to the donor as allowed by the IRS.

Endowment value at the end of the fiscal year, as reported in the annual NACUBO Endowment Study (changed to the NACUBOCommon Fund Study of Endowments in 2009).

Awards include: American Council of Learned Societies (ACLS) Fellows, Beckman Young Investigators, Burroughs Wellcome Fund Career Awards, Cottrell Scholars, Fulbright American Scholars, Getty Scholars in Residence, Guggenheim Fellows, Howard Hughes Medical Institute Investigators, Lasker Medical Research Awards, MacArthur Foundation Fellows, Andrew W. Mellon Foundation Distinguished Achievement Awards, National Endowment for the Humanities (NEH) Fellows, National Humanities Center Fellows, National Institutes of Health (NIH) MERIT, National Medal of Science and National Medal of Technology, NSF CAREER awards (excluding those who are also PECASE winners), Newberry Library Long-term Fellows, Pew Scholars in Biomedicine, Presidential Early Career Awards for Scientists and Engineers (PECASE), Robert Wood Johnson Policy Fellows, Searle Scholars, Sloan Research Fellows, Woodrow Wilson Fellows. As reported by the Top American Research Universities - see link. The number of National Academy members included in the National Academy of Sciences, National Academy of Engineering, and the Institute of Medicine.

As submitted to the National Science Foundation Survey of Graduate Students and Postdoctorates in Science \& Engineering (also known as the GSS). 
Number of Science \& Engineering Disciplines nationally ranked in Top 100 for research expenditures

Return on Investment

Total Research Expenditures (\$M)

Percent of R\&D Expenditures funded from External Sources

Patents Issued

Licenses/Options Executed

Licensing Income Received (\$M)

Number of Start-up Companies

Science \& Engineering Research Expenditures in non-medical/health sciences

National rank is higher than predicted by Financial Resources Ranking based on US News \& World Report

Research Doctoral Degrees Awarded

Professional Doctoral Degrees Awarded
The number of Science \& Engineering disciplines the university ranks in the top 100 (for public and private universities) based on the National Science Foundation's annual survey for R\&D expenditures, which identifies 8 broad disciplines within Science \& Engineering (Computer Science, Engineering, Environmental Science, Life Science, Mathematical Sciences, Physical Sciences, Psychology, and Social Sciences).

Total expenditures for all research activities (including non-science and engineering activities) as reported on the NSF annual survey. The percentage of total R\&D expenditures that come from Federal, Private Industry and Other sources (does not include State or Institutional funds).

The number of patents issued in the fiscal year as reported to AUTM.

Licenses/options executed in the fiscal year for all technologies as reported annually to the AUTM Licensing Survey. Each agreement is counted separately.

License issue fees, payments under options, annual minimums, running royalties, termination payments, amount of equity received when cashed-in, and software and biological material end-user license fees of $\$ 1,000$ or more, but not research funding, patent expense reimbursement, valuation of equity not cashed-in, software and biological material end-user license fees of less than $\$ 1,000$, or trademark licensing royalties from university insignia.

The number of start-up companies that were dependent upon the licensing of University technology for initiation as reported in the AUTM Licensing Survey.

This metric reports the Science \& Engineering total R\&D expenditures minus the research expenditures for medical sciences as reported by the National Science Foundation (see link, table 36 minus table 52).

This metric compares the overall national university ranking to the financial resources rank as reported by the US News and World report.

The number of research doctoral degrees awarded annually.

The number of professional doctoral degrees awarded annually. 